DOI: $\underline{\text { https://doi.org/10.31933/dijdbm.v2i5 }}$

Received: 10 March 2021, Revised: 13 July 2021, Publish: 31 August 2021

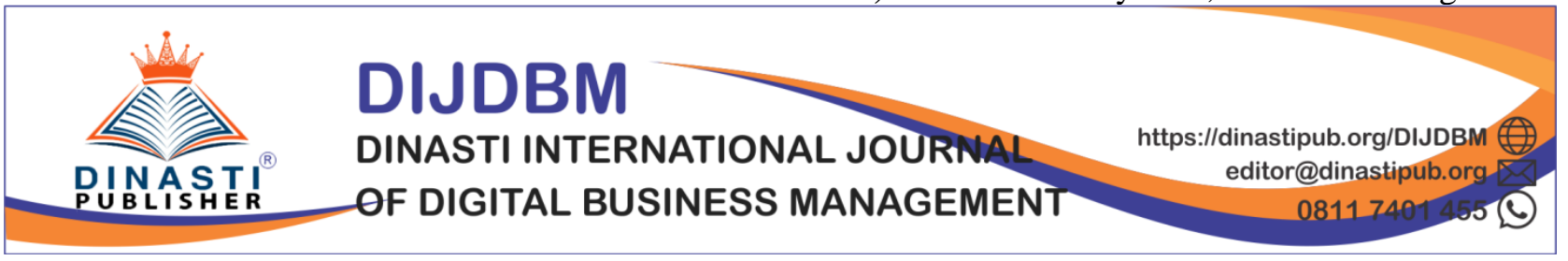

\title{
PROPOSED STRATEGY FOR PT RESIK NYAMAN SEJAHTERA PENETRATING CLEANING AND SECURITY SERVICE MARKET USING AHP METHOD
}

\author{
Raharja Indra', Prasetyo Hugo ${ }^{2}$ \\ 1) University of Mercubuana, Jakarta, Indonesia, indra.raharja@ mercubuana.ac.id \\ 2) University of Mercubuana, Jakarta, Indonesia, hugo.prasetyo@mercubuana.ac.id
}

\section{Corresponding Author: First Author ${ }^{1}$}

\begin{abstract}
The background of research is PT Resik Nyaman Sejahtera experiences several problems in the company: The company does not have clear targets, no marketing, human resources and operations programs, unstable sales, high employee turnover. Therefore, the purpose of this study is to determine the factors that affect cleaning and security service business in Jakarta. To find out the company's strategy can still compete with current conditions. To formulate a business strategy company's keeps the cleaning and security service business stay competitive in Jakarta. This research is a qualitative descriptive study by conducting interviews with owners, mapping the company's external and internal factors, weighting using Analytic Hierarchy Process, mapping company strategy with the Grand Matrix Strategy and Michael Porter's Five Generic Strategy. The results of this study provide the best strategies in marketing, operations, human resources, and corporate financial information systems in the next five years to achieve a competitive advantage.
\end{abstract}

Keywords: Cleaning, Security Services, Analytic Hierarchy Process, Grand Matrix Strategy

\section{INTRODUCTION}

In March 2020 Indonesia was hit by a health crisis problem, the existence of the coronavirus disease or better known as COVID-19 caused businesses to be paralyzed in various sectors, the education industry, which had been carrying out face-to-face activities, turned into Distance Learning, better known as PJJ. Many companies terminate employment with employees due to the absence of incoming money due to large-scale social restrictions imposed by the government. The existence of large-scale social restrictions has a positive impact on making Indonesians pay more attention to health and hygiene.

Services are any activity, benefit or performance offered by one party to another party that is intangible and does not cause any transfer of ownership, which in production is tied to or not with physical products (Kotler \& Keller, 2012).

Business is an entity created to produce goods and services to customers. Every business deals with people. Those people suffer the consequences for the business, them. Cross-functional cooperation in business is to emphasize the needs of managers from different functional areas to 
maximize profits in achieving common goals (Madura, 2011). While business strategy is a strategy to achieve goals that is often analogous to chess strategy, in which systematic thinking, planning, agility to move, courage to take risks and passion to win matches are some of the characteristics of chess that are relevant to business management practices (Joewono, 2012).

However, even though during the Covid-19 pandemic, business actors have implemented marketing strategies through social media, it is also necessary to pay close attention to the purchasing power of the community. (Budiman,2018) and Suhardi \& Herlina (Suhardi \& Herlina, 2010).

Based on an interview conducted with Mr. Wagiran as CEO of PT Resik Nyaman Sejahtera. The company experienced several difficulties:

1. The company does not have clear targets

2. Many projects are transferred to other companies in the following year.

3. The absence of marketing, human resources and operational programs

4. Difficulty in competing with similar competitors

5. Sales fluctuate

6. Many projects were postponed as a result of PSBB (Large-scale Social Restrictions).

7. High employee turnover ..

Based on the phenomenon of the problems above, it is interesting for researchers to examine the proposed strategies that PT Resik Nyaman Sejahtera must implement in penetrating the cleaning and security services market in Jakarta, in order to increase the competitiveness and sustainability of the company.

The research objectives of the proposed strategy for PT Resik Nyaman Sejahtera in penetrating the cleaning and security services market using the AHP method are as follows:

1. To determine the factors that affect the cleaning and security service business in Jakarta.

2. To find out the company's strategy is still able to compete with current conditions.

3. To formulate a business strategy PT Resik Nyaman Sejahtera keeps the cleaning and security services business competitive in Jakarta.

\section{LITERATURE REVIEW}

\section{Strategic Management}

Fred R David (2011) states that strategic management can be defined as the art and knowledge of formulating, implementing, and evaluating cross-functional decisions that enable an organization to achieve its goals. As required by this definition, strategic management focuses on efforts to integrate management, marketing, finance / accounting, production / operations, research and development, and computer information systems to achieve organizational success.

External Scanning is the monitoring, evaluation and dissemination of information from the external and internal environment to key people within the company. (Wheelen 2012: 98).

A. View of Industrial Organization

The Industrial Organization approach emphasizes that external / industry factors are more important than internal factors to achieve a competitive advantage. The performance of companies is mainly based on property industries, such as economic scale, market entry barriers, product differentiation, economy, and the level of competitiveness of internal resources, capabilities, structure, and operations. However, effective integration and understanding both external and internal factors are key to securing and maintaining a competitive advantage.

B. Economic Influences 
Kiani, N. I. (2016) Economic factors have a direct impact on the potential attractiveness of various strategies. Economic variables that are very influential in planning are the Gross Domestic Product, the trend in the value of the dollar currency and the unemployment rate.

C. Social, Cultural, Demographic, and Natural Environment Influences

Social, cultural, demographic and environmental changes have a profound impact on nearly all products, services, markets and customers. Small, large, for-profit, and non-profit organizations in all industries are reeling and challenged by the opportunities and threats arising from changing social, cultural, demographic and environmental variables.

D. Political, Governmental and Legal Influences

Pitoy, C. V., Tumbel, A., \& Tielung, M. (2016) Local government (Federal), Central Government, and Foreign Government are major regulators, deregulators, subsidizers, employers, and customers for an organization. Hence, they can serve as major opportunities or threats to either small or large organizations.

E. Influence of Technology

Prawiades. (2015) Revolutionary technological changes and inventions, have a dramatic influence in an organization. The Internet has changed the very nature of opportunities and threats by changing the cycle of a product, increasing the speed of distribution, creating new goods and services, removing the boundaries of traditional geographic markets, and changing the historical trade-off between product standardization and flexibility. .

F. Competitive Analysis: Porters Five-Forces Model

Foris, P. J., \& Mustamu, R. H. (2015) The nature of competitiveness in an industry can be seen from 5 compositions of strength / influence, namely:

1. Competition among (similar) companies

2. The potential for the entry of new competitors

3. The potential for the development of substitutes

4. The supply power of the supplier

5. The power of demand from consumers.

Internal Assesment : The basis for the purpose of an internal assessment is internal strengths and weaknesses, outside opportunities and threats, and a clear statement of purpose.

The key to internal strength is seen in the strengths of a business entity that competitors cannot match or emulate

(distinctive competencies). Building a competitive advantage can be done by taking advantage of distinctive competencies.

The process of conducting an internal audit Information is collected from:

1. Management

According to Kristiawan (2017) management is a science and art in regulating, controlling, communicating and utilizing all existing resources in the organization by utilizing management functions (Planing, Organizing, Actuating, Controling) so that organizations can achieve goals effectively and efficiently.

2. Marketing

In conducting an internal analysis of the marketing aspects, most of the business organizations use the marketing mix concept. The marketing mix is a combination of four variables which are the core of the company's marketing system, namely: product, price structure, distribution channel (place), and promotional activities (promotion) Tasurru, HH, \& Salehudin, I. ( 2014).

3. Finance and accounting 
In conducting an internal analysis on the financial aspect, the company can see the company's financial performance and its financial resources. Financial performance itself has the meaning of a formal business carried out by a company to evaluate the efficiency and effectiveness of the company's activities that have been carried out in a certain period of time. The financial performance of a company is generally measured based on net income (profit) or as a basis for other measurements such as return on investment or earnings per share (Harmono, 2014: 23).

\section{Production and operations}

The task of the production function in a company is to change inputs, namely raw materials into outputs in the form of finished products. According to Roger Schroeder in David (2011: 191) production / operations management consists of five decision areas or functions: process, capacity, inventory, labor and quality.

\section{Human Resources}

Human Resources are the driving force of work tools to achieve work goals. Strategic planners must be able to know and understand the relationship between HR and work tools and work targets to produce strategic advantages, therefore it is important for organizations to consider the strategies that the company will take with the company's human resource capabilities (Rivai and Prawironegoro, 2015: 75). .

6. Information management system

According to Laudon and Laudon's (2013: 47) information system can be defined as a series of interconnected components that collect (or get), process, store, and distribute information that supports decision-making and supervision within an organization. According to Sutabri (2012: 38), an information system is a system within an organization that brings together the needs of daily transaction processing that supports the managerial functions of the organization's operations with the strategic activities of an organization to be able to provide certain outsiders with the necessary reports. Analytical Hierarchy Process

Analytical Hierarchy Process The Analytical Hierarchy Process (AHP) was developed by Saaty (1993) and is used to solve complex or unframed problems where data and statistical information from the problems faced are very few Lidya \& Ronny (2018).

SWOT Analysis as a Strategy Formulation Tool

SWOT Analysis as a Strategy Formulation Tool SWOT analysis is the systematic identification of various factors to formulate a company strategy. This analysis is based on logic that maximizes strengths (Strengths) and opportunities (Opportunities), but simultaneously minimizes weaknesses (Weaknesses) and threats (Threats). The process of making strategic decisions is always related to the development of the mission, goals, strategies and company policies of Sulistiani, D. (2014). Thus the strategic planner (strategic planner) must analyze the company's strategic factors (strengths, weaknesses, opportunities and threats) in the current conditions. This is called a Situation Analysis. The appropriate model for this situation is the SWOT analysis of Sugiarto, F. F. (2016).

\section{Matrix EFE}

Porter (2018) The EFE matrix was created to assess the company's response to external conditions. The value of this matrix will then be entered into the Internal-External Matrix (IE Matrix) to determine the position of the company.

\section{Matrix IFE}

Porter (2018) The IFE matrix is made to see the strength / weakness of a company's internal conditions. The value of this matrix will then be entered into the Internal-External Matrix (IE Matrix) to determine the company's position.

\section{Grand Strategy Matrix}


According to Porter (2018), the Grand Strategy Matrix is used to formulate a company strategy by selecting two central variables in the process of determining the main goals of the Grand Strategy.

\section{RESEARCH METHODS \\ Research Design}

The approach of this research is quantitative, with the method of interviewing employees and filling out the audit checklist and the owner filling out the Analytical Hierarchy Process (AHP). AHP method is a decision making system using a mathematical model. AHP helps in determining the priority of several criteria by conducting pairwise comparative analysis of each criterion.

\section{Data Collection Techniques}

David (2011; 191-205) revealed that in data collection techniques there are 3 sources, namely: sources published on strategic information, sources from external information and sources of internal information.

A. Published sources of strategic information include
1. Magazine
2. Journal
3. Reports
4. Government documents
5. Summary
6. Books
7. Guidebook
8. Newspapers
9. User guide

B. Sources of External Information

In source or external audits information is gathered from:

1. Survey customers

2. Market research

3. Discussion at a meeting of experts or shareholders

4. Television programs

5. Interviews and talks with stakeholders

C. Internal information sources, internal sources of information are collected from:

1. Management

2. Marketing

3. Finance and accounting \

4. Production and operations

5. Research and development

6. Information management system

\section{Test Instruments (Consistency Ratio)}

Pranoto (2013) Respondents must have consistency in making element comparisons. - If it is known that $\mathrm{A}$ is a matrix of pairwise comparisons where our judgment is perfect for every comparison, then aij.ajk = aik applies to all $\mathrm{i}, \mathrm{j}, \mathrm{k}$. and then matrix $\mathrm{A}$ is said to be consistent - For example: if $\mathrm{A}>\mathrm{B}$ and $\mathrm{B}>\mathrm{C}$, then logically the respondent must state that $\mathrm{A}>\mathrm{C}$, based on the numerical values provided - Acceptable assessment results are those with CR $<10 \%(0.1)$

\section{FINDINGS AND DISCUSSION}


Bargaining power of suppliers in this business is relatively moderate because cleaning and safety materials and tools can be found anywhere, such as: chemicals and equipment can be purchased using e-commerce, then to provide labor needs in urban areas and in areas that are still very low. easy, many people who want to work so that the wages are relatively small.

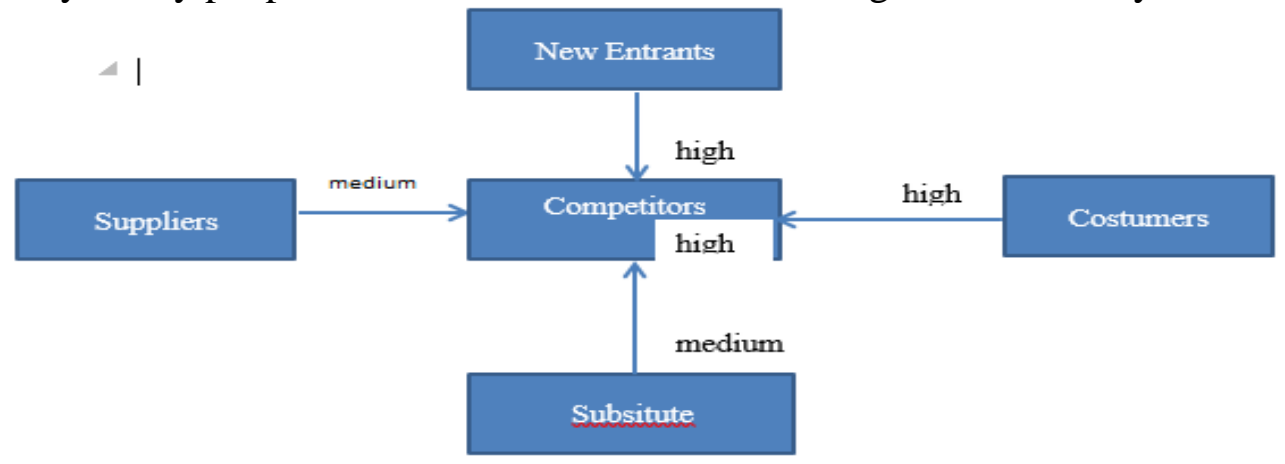

Table 1. Porter's Five Forces PT Resik Nyaman Sejahtera

Based on the Analytic Hierarchy Process, the consistency ratio (weight) value is $8.3 \%$ because it is less than $10 \%$ so it is considered acceptable. Assign a weight ranging from 0.0 (unimportant) to 1.0 (all important) for each factor. The weights assigned to certain factors indicate the relative importance of successful factors in the firm's industry. Assign a Rating between 1 and 4 for each key external factor to demonstrate hoe effectively, the company's current strategy responds to that factor, where 4 $=$ superior response, $3=$ above average response, $2=$ average response, $1=$ bad response.

Table 2. External weight assessment of the Company

\begin{tabular}{|c|c|c|c|}
\hline Key external success & Weight & Rating & Weighted Score \\
\hline \multicolumn{4}{|c|}{ Opportunities } \\
\hline $\begin{array}{l}\text { 1. People are starting to realize the importance of } \\
\text { cleanliness }\end{array}$ & $2.9 \%$ & 2 & 0.058 \\
\hline 2. Labor costs are relatively cheap in this industry & $22.5 \%$ & 2 & 0.45 \\
\hline $\begin{array}{l}\text { 3. Many people do not understand how to maintain } \\
\text { the cleanliness and safety of their assets / } \\
\text { property }\end{array}$ & $4.9 \%$ & 2 & 0.098 \\
\hline 4. Property growth tends to increase every year & $6.2 \%$ & 2 & 0.124 \\
\hline $\begin{array}{l}5 \text {. The need for contract labor increases every year } \\
\text { because companies are reluctant to cover their pension } \\
\text { costs }\end{array}$ & $21.9 \%$ & 3 & 0.657 \\
\hline \multicolumn{4}{|l|}{$\begin{array}{lc}\text { Threats } \\
\end{array}$} \\
\hline 1. Health Issues with Covid 19 & $6.5 \%$ & 2 & 0.13 \\
\hline 2. Indonesia's economic growth is not good enough & $5.5 \%$ & 2 & 0.11 \\
\hline 3. The high bargaining power of buyers & $18.3 \%$ & 3 & 0.549 \\
\hline 4. Large-scale social restrictions & $3.0 \%$ & 2 & 0.06 \\
\hline $\begin{array}{l}\text { 5. The high strength of the newcomers to this } \\
\text { Industry }\end{array}$ & $8.1 \%$ & 3 & 0.243 \\
\hline $\begin{array}{c}\text { TOTAL } \\
\end{array}$ & & & 2.479 \\
\hline
\end{tabular}


Table 3. Internal weight assessment

\begin{tabular}{|c|c|c|c|}
\hline Key Internal Success & weight & Rating & Weighted score \\
\hline \multicolumn{4}{|c|}{ Strenght } \\
\hline Human Resources (Operators) who have been trained. & $6.6 \%$ & 3 & 0.198 \\
\hline Competitive product prices. & $12.1 \%$ & 2 & 0.242 \\
\hline Have good quality standards with good raw materials. & $20.4 \%$ & 3 & 0.612 \\
\hline Complete work equipment and tools & $8.1 \%$ & 3 & 0.243 \\
\hline Have a good brand image and loyal customers. & $19.9 \%$ & 2 & 0.398 \\
\hline \multicolumn{4}{|c|}{ Weekness } \\
\hline High turnover employee & $2.5 \%$ & 3 & 0.075 \\
\hline $\begin{array}{l}\text { The company does not yet have employees who are } \\
\text { specifically in the marketing department. }\end{array}$ & $5.5 \%$ & 2 & 0.11 \\
\hline The company does not yet have a clear target. & $3.8 \%$ & 3 & 0.114 \\
\hline $\begin{array}{l}\text { The absence of a clear Human Resources, Marketing } \\
\text { and Operations program }\end{array}$ & $12.0 \%$ & 3 & 0.36 \\
\hline Sales are fluctuating & $9.0 \%$ & 3 & 0.27 \\
\hline TOTAL & & & 2.622 \\
\hline
\end{tabular}

Table 4. SWOT Analysis

\section{Strenght}

1.Human Resources (Operators) who have been trained.

2. Competitive product prices.

3. Have good quality standards with good raw materials.

4. Complete work equipment and tools

5. Have a good brand image and loyal customers.

\begin{tabular}{|ll|}
\hline \multicolumn{1}{|c|}{ Weakness } \\
\hline 1. & High turnover employee \\
\hline 2. & The company does not yet have employees who are specifically in the marketing department. \\
\hline 3. & The company does not yet have a clear target. \\
\hline 4. & The absence of a clear Human Resources, Marketing and Operations program \\
\hline 5. & Sales are fluctuating \\
\hline & \multicolumn{1}{c|}{ Opportunities } \\
\hline 1. & People are starting to realize the importance of cleanliness \\
\hline 2. & Labor costs are relatively cheap in this industry \\
\hline 3. & Many people do not understand how to maintain the cleanliness and safety of their assets / property \\
\hline 4. & Property growth tends to increase every year \\
\hline 5. & The need for contract labor increases every year because companies are reluctant to cover their pension \\
\hline & costs \\
\hline 1. & Health Issues with Covid 19 \\
\hline 2. & Indonesia's economic growth is not good enough \\
\hline 3. & The high bargaining power of buyers \\
\hline 4. & Large-scale social restrictions \\
\hline
\end{tabular}


5. The high strength of the newcomers to this Industry

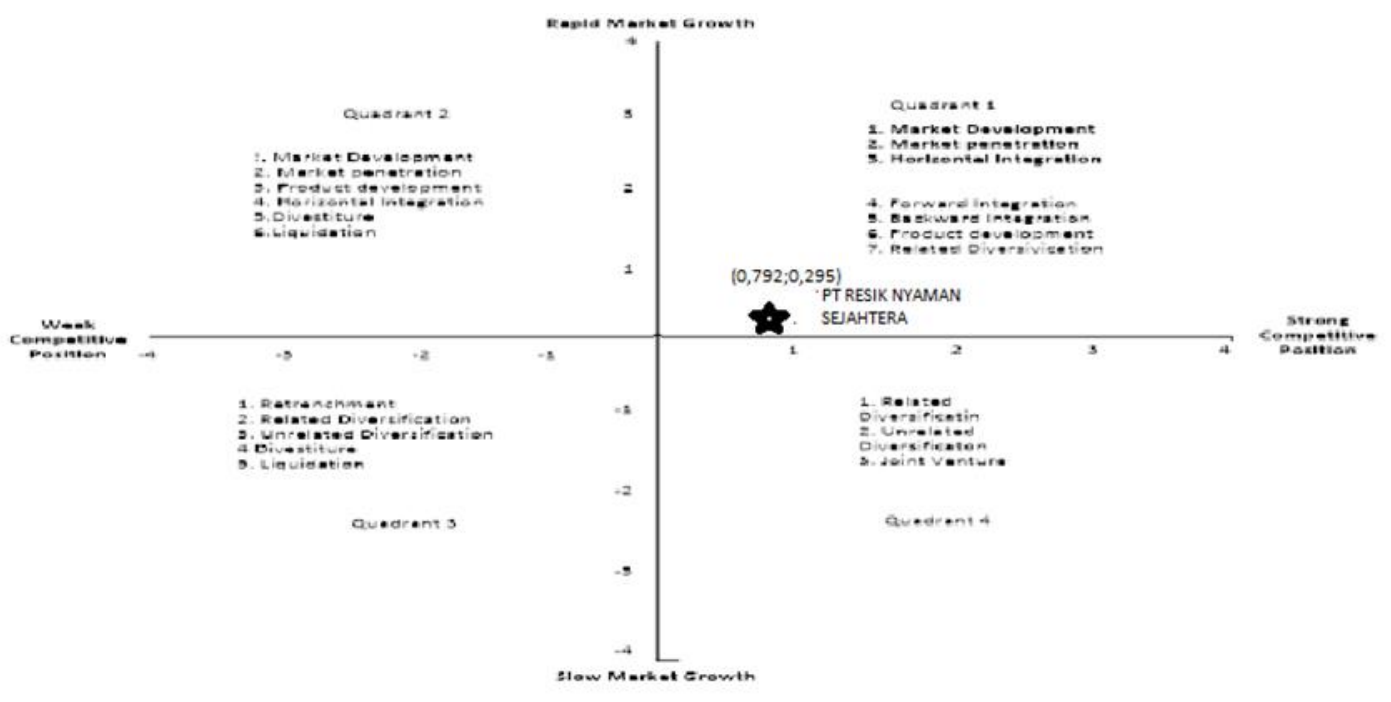

Picture 1. The Grand Strategy Matrix PT Resik Nyaman Sejahtera

The right strategy for PT Resik Nyaman Sejahtera to penetrate the market is an Intensive Strategy which concentrates on market development, market penetration and horizontal integration because PT Resik Nyaman Sejahtera is building a cleaning and security service market with existing products. Namely contract labor services such as security guards, cleaning services, receptionists, gardener and drivers who are professional and reliable. PT Resik Nyaman Sejahtera will also expand again to open up opportunities for the provision of cleaning and security services as well as contract workers in cities other than Jabodetabek in the next five years. PT Resik Nyaman Sejahtera does not apply a product development strategy intensively because it does not develop new products. Some of these strategies are mainly:

1. PT Resik Nyaman Sejahtera in building the lodging business market increases its marketing, especially in the area around Jabodetabek by optimizing the role of social media and working with new partners so as to build a strong brand image in this field.

2. PT Resik Nyaman Sejahtera in order to increase its market share and sales, especially in the next five years, intends to open branches in potential big cities in Java, such as /: Suci, Surabaya, Yogyakarta, etc.

3. In carrying out market development, PT Resik Nyaman Sejahtera is more concentrated on implementing inter-division program approaches, determining targets between divisions, conducting gradual certification, rearranging SOPs in accordance with health procedures and reducing activities or recruitment that are not related to the company's core business. so that employee productivity can increase

\section{CONCLUSION AND RECOMMENDATION}

\section{Conclusion}

The dominant factor in the cleaning and security service business is divided into two, namely: external and internal. External factors, namely: people are starting to realize the importance of cleanliness, labor costs are relatively cheap in this industry, many people do not understand the cleanliness and safety of their assets, health issues with Covid 19 and PSBB and companies are 
reluctant to bear their pension costs. The internal factor is product quality. good service, customer loyalty, competitive prices and qualified equipment.

The right strategy to win the cleaning and security business competition based on the Grand Strategy Matrix is in quadrant 1 (growth), the intensive strategy is market penetration, while the long-term strategy in less than five years is market development and integration. horizontally. Based on Michael Proter Lima's public lodging strategy, PT Resik Nyaman Sejahter is one that focuses on low-cost leadership.

\section{Recomendation}

Some action plans for implementing competitiveness for the next five years are Collaborating with new business partners, making clear marketing targets and activities, providing marketing activities through social media, providing product offers at affordable prices to partners, providing special offers when will renew new contracts with partners, provide continuous offer letters to new partners, maximize marketing by utilizing existing business networks, maintain good communication with customers, make product innovations that can reach home and apartment consumers, look for professional suppliers that offer materials premium raw materials at low prices, investing in the purchase of new machines, carrying out warehouse maintenance properly, implementing health protocols in standard operating procedures, buying raw materials directly from large party suppliers, testing swab tests on employees n field regularly, limiting the purchase of equipment that has nothing to do with the company's core business, improving cash flow and balance sheets, providing reward programs to employees who excel at least once every 6 months, making work programs in the fields of operations, human resources and finance can be measured, conduct coordination between divisions, conduct periodic certifications to employees, start thinking about investing in the field of hygiene and safety technology.

\section{BIBLIOGRAPHY}

Budiman, J. (2018). Pengaruh Daya Beli Masyarakat dan Strategi Pemasaran Dalam Meningkatkan Hasil Penjualan Pada Bisnis Property. Jurnal Keilmuan dan Aplikasi Teknik, 5(1), 1-6. http://akrabjuara.com/index.php/akrabjuara/article/view/868.

David, Fred R. 2011. Strategic Management, Buku 1. Edisi 12. Jakarta.

Foris, P. J., \& Mustamu, R. H. (2015). Analisis Strategi pada Perusahaan Plastik dengan Porter FIve Forces. AGORA Vol.3, No. 1. https://media.neliti.com/media/publications/36308-ID-analisisstrategi-pada-perusahaan-plastik-dengan-porter-five-forces.pdf.

Fred R. David (2013) Strategic Management: Concepts and Cases : a Competitive Advantage Approach, : Pearson.

Harmono. 2014. Manajemen Keuangan Berbasis Balanced Scorecard. Jakarta : Bumi Aksara.

Joewono, H. (2012). The Five Arrows of Strategy Management. Jakarta: Arbey.

Kiani, N. I. (2016). konsumen, dan minat beli ulang di kafe kopi spesialti Kota Bandung. 9th Industrial Reseatch Workshop and Neminar. https://doi.org/10.1016/j.foodqual.2012.02.009..

Kotler \& Keller, (2012). Manajemen Pemasaran. Edisi 12. Jakarta; Erlangga

Kristiawan, M., Safitri, D., \& Lestari, R. (2017). Manajemen Pendidikan. Yogyakarta: Deepublish. Laudon, K.C. dan Laudon, J.P. 2013. Management Information Systems: Managing the Digital Firm, $12^{\text {th }}$ edition. Pearson Education Limited. 
Lidya \& Ronny (2018), Analisis Strategi Bersaing pada Perusahaan Jasa Kebersihan, AGORA Vol. 6, No. 2. https://media.neliti.com/media/publications/287134-analisis-strategi-bersaing-padaperusaha-903ec8c5.pdf

Lucky, M. (2020), Penerapan Strategi Bisnis Di Masa Pandemi Covid 19, Jurnal IKRA-ITH Ekonomik, 4(1), 122-125. https://journals.upi-yai.ac.id/index.php/IKRAITHEKONOMIKA/article/view/1064..

Madura, Jeff., dan Fox, Roland. 2011. International Financial Management. Boston: Cengage Learning.

Nanang Martono. 2010. Metode Penelitian Kuantitatif: Analisa isi dan Analisis data sekunder. Jakarta. Raja Grafindo Persada.

Pitoy, C. V., Tumbel, A., \& Tielung, M. (2016). Analisis Strategi Bersaing dalam Persaingan Usaha Bisnis Document Solution (Studi Kasus pada PT Astragraphia, Tbk Manado). Berkala Ilmiah Efisiensi. https://ejournal.unsrat.ac.id/index.php/jbie/article/view/13320.

Porter, Michael E. 2018. Keunggulan Bersaing: Menciptakan dan Mempertahankan Kinerja Unggul. Cetakan ke-2. Jakarta. PT. Gelora Aksara Pratam.

Porter, M. E. (2011). Keunggulan Bersaing. Tangerang Selatan: KARISMA Publishing

Pranoto, Yosep Agus, M.Aziz Muslim dan Rini Nur Hasanah. 2013. Rancang Bangun dan Analisis Decision Support System Menggunakan Metode Analytical Hierarchy Process untuk Penilaian Kinerja Karyawan. Malang: Jurnal EECCIS Vol. 7, No. 1, Juni 2013: 91-96. https://jurnaleeccis.ub.ac.id/index.php/eeccis/article/view/209.

Prawiades. (2015). Analisis Strategi Bersaing Industri Bisnis Farmasi/Apotek di Kota Pekanbaru. JOM FISIP Vol 2 No. 2. Group. file://C:/Users/ASUS/Downloads/7528-14455-1-SM.pdf..

Prospek Bisnis Cleaning Service Menggiurkan. (2020, March 12). Retrieved December 1, 2020, from http://entrepreneur.bisnis.com/read/20140312/263/210128 “

Putra, I. S. (2017). Analisis Strategi Bersaing pada PT Anugerah Dwi Abadi. AGORA Vol. 5 No. 1. http://publication.petra.ac.id/index.php/manajemen-bisnis/article/view/5302.

Rivai, Abdul dan Darsono Prawironegoro. 2015. Manajemen Strategis Kajian Manajemen Strategis Berdasarkan Perubahan Lingkungan Bisnis, Ekonomi, Sosial dan Politik. Bekasi : Mitra Wacana Medika.

Sugiarto, F. F. (2016). Analisa Strategi Bersaing PT. Surya Cipta Mandiri. AGORA Vol. 4, No.2. https://media.neliti.com/media/publications/56264-ID-none.pdf.

Sajid, Syahmi., 2019. Jumlah dan Pertumbuhan Penduduk Indonesia. [online] Quoted from http://ipsgampang.blogspot.com/2014/08/jumlah-dan-pertumbuhan-penduduk.html

[Accessed Desember, 1-2020]

Suhardi, A., \& Herlina. (2010). Pengaruh Daya Beli Masyarakat Terhadap Nilai Penjualan Ikan Lele di Desa Ganjaran Kec. Pagelaran Kabupaten Pringsewu (Studi kasus pada Kelompok Pembudidaya Ikan Desa Ganjaran Kecamatan Pagelaran KabupatenPringsewu). Jurnal Manajemen dan Keuangan, $\quad 8(1), \quad 40-47$. https://jurnal.darmajaya.ac.id/index.php/jmk/article/view/290

Sulistiani, D. (2014). Mencapai keunggulan bersaing dengan strategi diferensiasi. EL MUHASABA

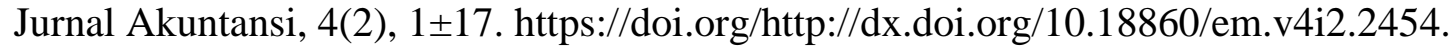

Sutabri, T. 2012. Analisis Sistem Informasi. Andi. Yogyakarta.

Tasurru, H. H., \& Salehudin, I. (2014). Global Brands and Consumer Ethnocentrism of Youth Soft Drink Consumers in Greater Jakarta, Indonesia. ASEAN Marketing Journal, 6(2), 77-88. https://doi.org/10.21002/amj.v6i2.4212

Wheelen, T. and Hunger, J. (2012). Strategic management and business policy. Upper Saddle River, N.J.: Pearson Prentice Hall. 


\section{Thank-you Note}

Raharja Indra has obtained his Bachelor's (2015), and Master (2017) degrees in Institut Technology Bandung, Bandung-Indonesia in School Business Management. He has been a lecturer since August 2019 at the Mercu Buana University. Focus of his research is on business strategic company. Researcher would like to express their deepest gratitude to the University of Mercu Buana Research Center for funding this research. 